\title{
Familial papillary thyroid carcinoma with renal papillary neoplasia
}

INSERM

\section{Source}

INSERM. (1999). Orphanet: an online rare disease and orphan drug data base. Familial papillary thyroid carcinoma with renal papillary neoplasia. ORPHA:97290

Familial papillary thyroid carcinoma with renal papillary neoplasia (fPTC/PRN) is an extremely rare inherited tumor syndrome within the familial nonmedullary thyroid cancer group (fNMTC; see this term). 